\title{
Separation and preconcentration procedures for the determination of lead using spectrometric techniques: A review
}

\author{
Maria das Graças A. Korn ${ }^{a}$, Jailson B. de Andrade ${ }^{a}$, Djane S. de Jesus ${ }^{a}$, b , Valfredo A. Lemos ${ }^{c}$, \\ Marcus L.S.F. Bandeira ${ }^{\mathrm{a}, \mathrm{d}}$, Walter N.L. dos Santos ${ }^{\mathrm{a}}$, Marcos A. Bezerra ${ }^{\mathrm{a}, \mathrm{c}}$, \\ Fabio A.C. Amorim ${ }^{a}$, Anderson S. Souza ${ }^{\text {a,c }}$, Sergio L.C. Ferreira ${ }^{\mathrm{a}, *}$ \\ ${ }^{a}$ Universidade Federal da Bahia, Instituto de Química, Campus Universitário de Ondina, 40170-290 Salvador, BA, Brazil \\ b Centro Federal de Educação Tecnológica da Bahia, Rua Emidio Santos, s/n-Barbalho, Salvador, BA, Brazil \\ ${ }^{c}$ Universidade Estadual do Sudoeste da Bahia, Departamento de Química e Exatas, Campus de Jequié, 45200-190 Jequié, BA, Brazil \\ ${ }^{\mathrm{d}}$ Faculdade de Tecnologia e Ciências, Av. Luís Viana Filho, 8812 Paralela Salvador, BA, Brazil
}

Received 24 September 2005; received in revised form 28 October 2005; accepted 29 October 2005

Available online 18 January 2006

\begin{abstract}
Lead is recognized worldwide as a poisonous metal. Thus, the determination of this element is often required in environmental, biological, food and geological samples. However, these analyses are difficult because such samples contain relatively low concentrations of lead, which fall below the detection limit of conventional analytical techniques such as flame atomic absorption spectrometry and inductively coupled plasma optical emission spectrometry. Several preconcentration procedures to determine lead have therefore been devised, involving separation techniques such as liquid-liquid extraction, solid phase extraction, coprecipitation and cloud point extraction. Citing 160 references, this paper offers a critical review of preconcentration procedures for determining lead using spectroanalytical techniques.
\end{abstract}

(C) 2005 Elsevier B.V. All rights reserved.

Keywords: Lead; Preconcentration and separation techniques; Flame atomic absorption spectrometry (FAAS); Inductively coupled plasma optical emission spectrometry (ICP OES)

\section{Contents}

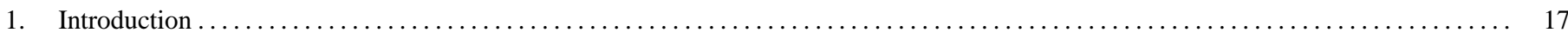

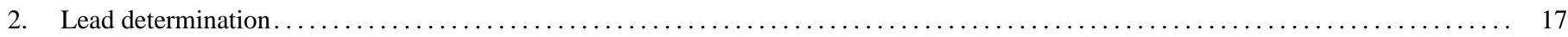

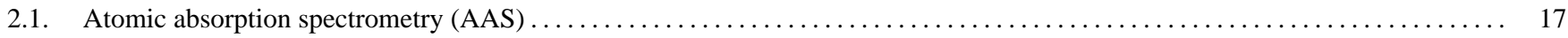

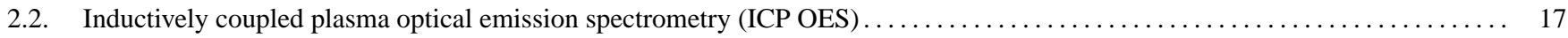

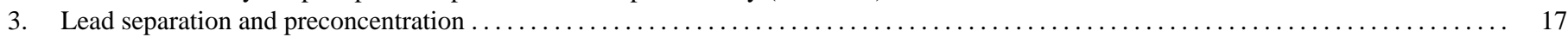

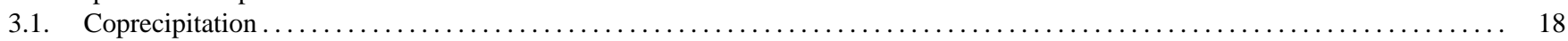

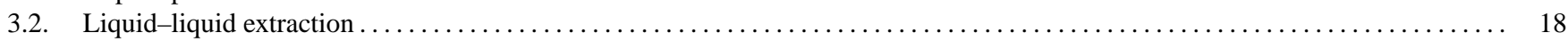

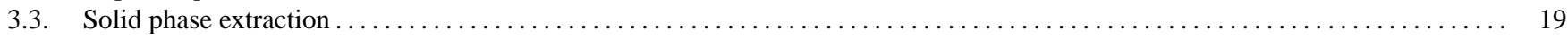

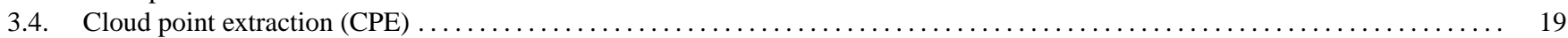

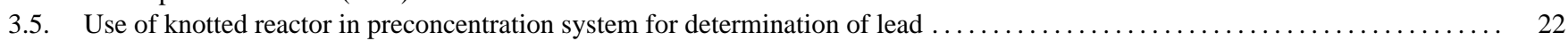

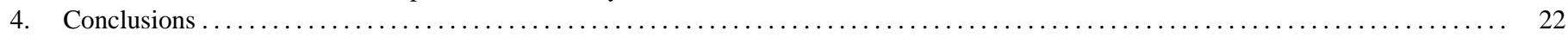

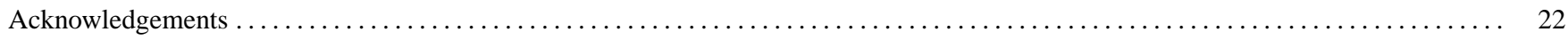

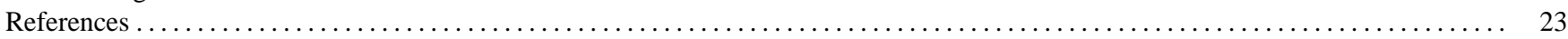

\footnotetext{
* Corresponding author. Fax: +55 7132355166.

E-mailaddresses: slcf@ufba.br, sergio1057@ hotmail.com (S.L.C. Ferreira).
} 


\section{Introduction}

The word lead derives from the Anglo-Saxon leaden, and the symbol Pb, from the Latin word for lead, Plumbum. Lead is by far the most abundant (13 ppm) heavy element in the earth's crust. It is one of the few metals that can be found in metallic form in nature (rather than in compounds that must be reduced to extract metal). Lead, a lustrous bluish-white metal, is very soft, highly malleable, ductile and a relatively poor conductor of electricity. It is highly corrosion resistant but tarnishes under exposure to air [1-4].

Lead is an ancient metal, having been known since before recorded history. It is one of the oldest metals known to man and is mentioned in the Old Testament. In Ancient Egypt (7000-5000 в.C.), lead was used in pottery glazing and the Hanging Gardens of Babylon were floored with lead slabs to guard against moisture. The Roman Empire used lead extensively for water pipes and plumbing, some of which is still in use today. The Romans also used lead to manufacture cooking utensils. Studies suggest that the Roman civilization fell largely as a result of widespread lead poisoning. This theory is supported by data showing high lead concentrations in the bones of ancient Romans. In the Middle Ages, the practice of "sweetening" wine with lead or lead acetate became a serious toxicological problem. In those days, the alchemists believed lead was the oldest metal and made innumerable attempts to transform it into gold [3-5].

Our environment contains countless sources of lead, which is a natural component of soil, water, vegetation, animal life and air [6-10]. In the modern world, it is ubiquitous in food, water and air. Lead is now known to be a poison [5,11] absorbed into the bloodstream, from where, especially in the case of inorganic lead, it is distributed to soft tissue, bones and teeth $(95 \%$ in bones and teeth). Organic forms of lead are fat soluble and therefore have a particular tendency to concentrate in brain [12].

The mechanism of absorption is not yet completely clear, but lead is believed to bind to oxo-groups in enzymes, affecting virtually every step in heme synthesis and porphyrin methabolism. It also inhibits acethylcholinesterase, acid phosphatase, ATPase, etc. Typical symptoms of lead poisoning are abdominal pain, anaemia, headaches and convulsions, chronic nephritis of the kidney, brain damage and central nervous-system disorders. Safe lead stripping from the body remains a major challenge. Due to the poisoning properties of lead, the industrialized countries have banned the use of lead in two practically universal forms - tetraethyl lead and lead-based paints for home use. Until recently, lead poisoning was diagnosed based on its symptoms; however, today it is diagnosed by analyzing its presence in blood using atomic absorption methods $[1,5,6]$.

\section{Lead determination}

\subsection{Atomic absorption spectrometry (AAS)}

The determination of lead by flame atomic absorption spectrometry (FAAS) is practically free of interference and requires an air-acetylene flame [13]. The interference caused by alu- minum and iron can be overcome by the addition of ascorbic acid, citric acid and EDTA [13]. The threshold of sensitivity of this technique is very low (LOD $0.01 \mathrm{mg} \mathrm{L}^{-1}$ ) and is often unsuitable for trace analysis [13]. In this sense, many preconcentration procedures must be performed to determine trace amounts of lead, as indicated in the tables shown here. The most important analytical lines of lead are 217.00 and $283.31 \mathrm{~nm}$. The $217.00 \mathrm{~nm}$ line is more sensitive, notwithstanding the greater amount of background absorption effects [13].

Electrothermal atomic absorption spectrometry (ETAAS) is a good alternative for determining trace amounts of lead in several types of samples in view of its good sensitivity [13]. However, in some cases, previous preconcentration and separation steps are carried out before analytical measurements by ETAAS.

The use of a modifier stabilizes lead, allowing for its determination without causing matrix effects. The $\mathrm{Pd}-\mathrm{Mg}$ modifier is the one most commonly used, since it produces the best results. This modifier allows for the application of pyrolysis temperatures ranging from 1200 to $1400^{\circ} \mathrm{C}$, which enables the separation of most interfering elements [13-17]. The stabilizing effect of this modifier also raises the atomization temperature to $2000^{\circ} \mathrm{C}$, which allows a characteristic mass of about $16 \mathrm{pg}$ [13]. Ammonium phosphate is another modifier frequently used for determining lead by ETAAS, allowing for an atomization temperature of $1600^{\circ} \mathrm{C}$ and enabling a low characteristic mass of $12 \mathrm{pg}[13,18]$.

\subsection{Inductively coupled plasma optical emission spectrometry (ICP OES)}

Inductively coupled plasma optical emission spectrometry is an analytical technique often employed to determine lead in various types of samples [19]. The main emission lines are: $\mathrm{Pb}$ II $220.353 \mathrm{~nm}, \mathrm{~Pb}$ I $216.999 \mathrm{~nm}$ and $\mathrm{Pb}$ I $283.306 \mathrm{~nm}$, with $220.353 \mathrm{~nm}$ being the most sensitive. However, the low level of lead in many samples lies below the detection limit of this technique. Moreover, several types of spectral interference have been reported in the determination of lead by ICP OES. Virtually all photomultiplier-based ICP spectrometers use the $\mathrm{Pb}$ $220.353 \mathrm{~nm}$ analytical line, despite its severe background continuum and inter-element interference from $\mathrm{Al} 220.4 \mathrm{~nm}$ and background shift due to iron $(\mathrm{Fe})$. Direct spectral overlap interference due to iron has also been found in the 216.9 and $283.9 \mathrm{~nm}$ analytical lines $[20,21]$. Thus, preconcentration and separation procedures have been devised to allow trace amounts of lead to be determined in complex matrices using ICP OES. Several tables shown in this paper summarize the use of separation techniques such as liquid-liquid extraction, solid phase extraction, cloud point extraction and others, as pre-steps in determining lead using ICP OES.

\section{Lead separation and preconcentration}

Separation techniques such as coprecipitation [23,50], liquid-liquid extraction [57-60], solid phase extraction [69-134] and more recently, cloud point extraction [139-146,150] and on-line coprecipitation using a knotted reac- 
tor [150-160] have been successfully employed to determine trace levels of lead. Each technique has its pros and cons and should be chosen according to the analytical problem.

\subsection{Coprecipitation}

Coprecipitation is one of the most efficient separation/enrichment techniques for trace heavy metal ions. The main requirement for this technique is that the collector should separate easily from the matrix solution. This can be done by filtering, centrifuging and washing of the precipitate. In addition, it is desirable that the collector should be a pure and readily available substance. The advantages of this technique are its simplicity and the fact that various analyte ions can be preconcentrated and separated simultaneously from the matrix. Inorganic or organic coprecipitants have been used as efficient collectors of trace elements. However, this process is slow and samples sometimes have to be kept over-night for complete coprecipitation [22]. This technique has been widely applied in preconcentration procedures for determining lead in water samples. Inorganic coprecipitants such as manganese dioxide and aluminum, gallium, cerium(IV), erbium, iron(III), magnesium, samarium and zirconium hydroxides have been widely and successfully used for preconcentrating trace lead ions from different mediums $[23,50]$. A fast procedure for separation and preconcentration using ultrasound-assisted coprecipitation with manganese diox- ide has recently been proposed for determining lead in environmental samples by ICP OES [18]. Coprecipitation parameters, including concentration of oxidizing agent- $\mathrm{KMnO}_{4}$, concentration of $\mathrm{MnSO}_{4}$ and exposure time to ultrasound irradiation, are discussed. The time required for coprecipitation is about $60 \mathrm{~s}$. Another paper proposed an aluminum hydroxide coprecipitation method for the determination of trace amounts of $\mathrm{Cu}, \mathrm{Cd}$ and $\mathrm{Pb}$ by FAAS in seawater and mineral water after a 125 -fold preconcentration [19]. Table 1 lists several methods for determining lead in many samples, using coprecipitation as the separation and preconcentration technique.

\subsection{Liquid-liquid extraction}

Solvent extraction has been one of the most extensively studied and widely applied methods in preconcentration and separation procedures for the determination of trace elements due to its simplicity, convenience, wide scope, etc. In this technique, the metal is distributed between two immiscible liquid phases (usually an aqueous and an organic phase). Metal ion stripping from aqueous solution to organic phase takes place after a complexation reaction. For the analytical measurement, the extracted metal ion can be directly measured in organic extract or a backextraction step is carried out in an aqueous medium, usually acid [51-53]. Separation and preconcentration procedures using solvent extraction generally result in a high enrichment factor due

Table 1

Preconcentration procedures using coprecipitation for the determination of lead

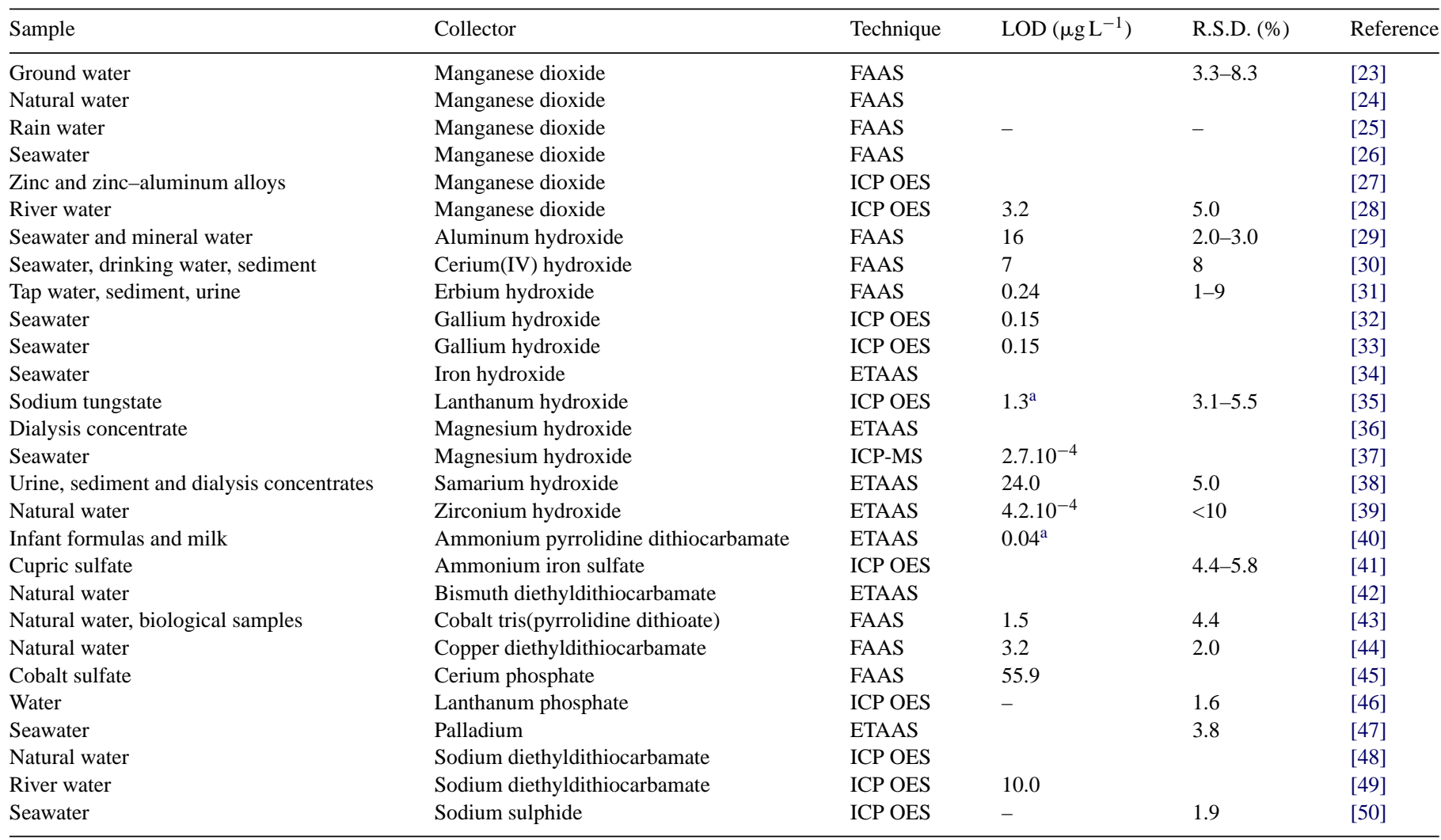

\footnotetext{
** $\mathrm{pg} / \mathrm{mL}$

a $\mathrm{ng} / \mathrm{g}$.
} 
Table 2

Procedures for lead preconcentration based on solvent extraction

\begin{tabular}{|c|c|c|c|c|c|}
\hline Sample & Technique & Complexation agents & Solvent & Enrichment factor & Reference \\
\hline Table salt & FAAS & Dithizone & $\mathrm{MIBK}^{\mathrm{a}}$ & 99 & {$[57]$} \\
\hline Waste water & FAAS & $\mathrm{HBDAP}^{\mathrm{b}}$ & $\mathrm{HNO}_{3} / \mathrm{HCl}$ & - & {$[58]$} \\
\hline Estuarine water & GFAAS & $\mathrm{APDC}^{\mathrm{c}}$ and $\mathrm{DDC}^{\mathrm{d}}$ & - & - & {$[59]$} \\
\hline Urine and CRF & ICP-MS & APDC & $\mathrm{MIBK} / \mathrm{HNO}_{3}$ & 23.3 & {$[60]$} \\
\hline High-purity aluminum salts & ICP OES & APDC & $\mathrm{HNO}_{3} / \mathrm{H}_{2} \mathrm{O}_{2}$ & - & {$[61]$} \\
\hline Natural water & FAAS & Dithizone & Xylene & - & {$[62]$} \\
\hline Natural water & FAAS & Dithizone & $\mathrm{HNO}_{3}$ & 543 & {$[63]$} \\
\hline Aragonite & ETAAS & $\mathrm{NaDDC}$ & MIBK & - & {$[64]$} \\
\hline Water & FAAS & APDC & MIBK & - & {$[65]$} \\
\hline Seawater & ICP-MS & $\mathrm{DDC}$ & & & {$[66]$} \\
\hline Drinking and bore well waters & FAAS & $\mathrm{CMPQ}^{\mathrm{e}}$ & & - & [67] \\
\hline
\end{tabular}

\footnotetext{
a Methylisobutyl ketone.

b $N, N^{\prime}$-bis(2-hydroxy-5-bromo-benzyl)-1,2 diaminopropane.

c Ammonium pyrrolidinedithiocarbamate.

d Diethyldithiocarbamate.

e 5-(2'-Carbomethoxyphenyl)azo-8-quinolinol.
}

to the difference between the volumes of aqueous and organic phases. Although this procedure is operated in batch mode, it is time-consuming and produces large amounts of potentially toxic organic solvents as waste. The implementation of methods in continuous mode overcomes these drawbacks. Such unit operations are, instead, carried out in flow injection (FI) and/or sequential injection (SI) systems, which, besides reducing sample and reagent consumption, allow all manipulations to be done automatically in an enclosed environment, thus minimizing the risk of sample contamination. Analytical procedures for lead separation and preconcentration by solvent extraction and determination by atomic spectrometric techniques have been widely applied since these techniques were invented [54]. Procedures in flow injection systems for separation and preconcentration with the application of solvent extraction to determine metals, including lead, are extensively discussed in the literature $[55,56]$. Table 2 lists several analytical systems proposed for lead separation and preconcentration by solvent extraction and lead determination using atomic spectrometric techniques.

\subsection{Solid phase extraction}

Solid phase extraction is based on the partition between a liquid (sample matrix) and a solid phase (sorbent). Several sorbents coupled to detection systems have been used for lead preconcentration and determination. The basic approach is the contact of a liquid sample through a column, a flask, a cartridge, a tube or a disk containing an adsorbent that retains lead ions. After this first step, the retained lead is recovered upon elution with an appropriate solvent [68].

Sorbents used in preconcentration systems for lead determination can be unloaded, loaded or chemically modified with the help of complexing reagents. Unloaded supports are potential collectors of analytes in the form of a single ion or associated with other species such as complexes. The sorbents in this class include activated carbon [69], natural adsorbents [70], Amberlite XAD resins [71-75], polyethylene [76] and others [77]. Lead can also be complexed with ligands loaded in several supports, such as polyurethane foam [78-80], activated carbon [81] and polymeric materials [82-84], which make for efficient preconcentration procedures. Many reagents have been used to load these supports and to retain lead ions by complexation. These include: $2-\left(2^{\prime}\right.$-thiazolylazo $)-p$ cresol (TAC) [85], 2-propylpiperidine-1-carbodithioate [86], 2-(2-benzothiazolylazo)-2-p-cresol (BTAC) [80,87], pyrogallol red [81], 1-(2-pyridylazo)-2-naphthol (PAN) [88], dithizone $[89,90]$ and 2-(5-bromo-2-pyridylazo)-5-diethyl-aminophenol (5-Br-PADAP) [91]. Supports can also be functionalized with chelating reagents, which render them powerful absorbents for lead preconcentration. Supports such as Amberlite XAD series [92,93], silica gel [94-96] and cellulose [97,84] have been modified with reagents by several routes. Several methods have been proposed for preconcentrating lead using the solid phase batch extraction procedure (Table 3).

Many papers have reported on-line preconcentration systems followed by lead determination with several detectors. Selected applications are reported in Table 4. Sorbents used in FI systems provide rapid sorption and desorption of lead. Organic solvents can be used as eluants, leading to a high sensitivity in some detectors such as FAAS.

\subsection{Cloud point extraction (CPE)}

The cloud point phenomenon occurs when a nonionic or amphoteric surfactant above its critical micellar concentration (CMC) causes the separation of the original solution into two phases when heated at a characteristic temperature called cloud point temperature. Above the cloud point, micelles formed from surfactant molecules act as an organic solvent in liquid-liquid extraction and the analytes are partitioned between the micellar and aqueous phases [135-137]. Thus, metallic elements can be extracted to a surfactant-rich phase, trapped in the hydrophobic micellar core, in the form of hydrophobic complexes that are formed between the metal ion and an appropriate chelating agent under adequate conditions. An evaluation of the partition coefficients of ligands and complexes involved is, therefore, 
Table 3

Off-line procedures for lead preconcentration using solid phase extraction

\begin{tabular}{|c|c|c|c|c|c|}
\hline Sample & Sorbent & Technique & $\begin{array}{l}\text { Limit of } \\
\text { detection } \\
\left(\mu \mathrm{gL}^{-1}\right)\end{array}$ & $\begin{array}{l}\text { Enrichment } \\
\text { factor }\end{array}$ & Reference \\
\hline Seawater & Amberlite XAD-1180 & FAAS & - & - & {$[71]$} \\
\hline Environmental samples & Amberlite XAD-4 & FAAS & - & - & {$[72]$} \\
\hline Seawater & Amberlite XAD-16 & FAAS & - & 150 & {$[73]$} \\
\hline Waste water & Pyrogallol red loaded active carbon & FAAS & $1.00 \times 10^{-3}$ & 100 & [81] \\
\hline Soil and water samples & Chromosorb 102 & FAAS & 2.00 & - & {$[82]$} \\
\hline Steel & $\operatorname{PbSpec}(\mathrm{TM})$ & FAAS & 50.00 & 0.50 & {$[83]$} \\
\hline Seawater & $\begin{array}{l}\text { 1-(2-Pyridylazo)-2-naphthol loaded Amberlite } \\
\text { XAD-4 }\end{array}$ & FAAS & $5.00 \times 10^{-3}$ & 12000 & {$[88]$} \\
\hline Saline matrices & Dithizone co-crystallized with naphthalene & ICP OES & 47 & 13 & [89] \\
\hline $\begin{array}{l}\text { Tap water, well water, river water, } \\
\text { vegetable extract and milk samples }\end{array}$ & $\begin{array}{l}\text { Dithizone immobilized on sodium dodecyl sulfate } \\
\text { coated alumina }\end{array}$ & FAAS & - & 200 & {$[90]$} \\
\hline River and tap water & $\begin{array}{l}\text { Chromotropic acid anchored on Amberlite XAD-2 } \\
\text { Pyrocatechol anchored on Amberlite XAD-2 } \\
\text { Thiosalicylic acid anchored on Amberlite XAD-2 } \\
\text { Xylenol orange loaded Amberlite XAD-7 }\end{array}$ & FAAS $^{a}$ & $\begin{array}{l}4.06 \\
3.80 \\
4.87 \\
2.44\end{array}$ & $\begin{array}{l}200 \\
100 \\
100 \\
100\end{array}$ & {$[92]$} \\
\hline River water & Quinalizarin anchored in Amberlite XAD-4 & FAAS & - & - & [93] \\
\hline Seawater & 3-Aminopropyltriethoxysilane modified silica gel & GFAAS & 4.00 & - & {$[95]$} \\
\hline Solar salt and water & Cellulose functionalized with thioglycolic acid & - & - & - & [97] \\
\hline Water & Diaion HP-2MG & FAAS & 3.3 & - & {$[98]$} \\
\hline Seawater & Naphthalene/alizarin red & $\mathrm{ICP}_{\mathrm{OES}}^{\mathrm{b}}$ & 53.0 & 40 & [99] \\
\hline Certified reference seawater & $\begin{array}{l}\text { Sephadex A-25 loaded with } \\
\text { thiacalix[4]arenetetrasulfonate }\end{array}$ & GFAAS $^{c}$ & 0.20 & 100 & {$[100]$} \\
\hline $\begin{array}{l}\text { Water, waste water, black tea and hot } \\
\text { pepper }\end{array}$ & $\begin{array}{l}\text { Octadecyl-bonded silica modified by } \\
\text { [bis }(2,4 \text {-dimethoxy benzaldehyde) ethylen diimine] } \\
\text { (TDSB) }\end{array}$ & ICP OES & 0.15 & 500 & {$[101]$} \\
\hline Black tea and black and hot pepper & Modified hexagonal mesoporous silica & ICP OES & 0.34 & 500 & {$[102]$} \\
\hline Soil & Microcrystalline naphthalene & FAAS & 2.5 & 200 & {$[103]$} \\
\hline Black tea and natural water & Chelex-100 & FAAS & - & - & {$[104]$} \\
\hline River and tap water samples & $o$-Dihydroxybenzene anchored on silica gel & FAAS & 4.00 & 250 & {$[105]$} \\
\hline Natural water, milk, red wine and rice & Diaion HP-2MG & FAAS & 0.25 & 375 & {$[106]$} \\
\hline Water & Commercial C-18 & FAAS & 0.20 & 129 & {$[107]$} \\
\hline Water & Homemade C-18 & FAAS & 0.60 & 125 & \\
\hline Industrial and river waters & $\begin{array}{l}\text { Silica gel chemically modified with zirconium } \\
\text { phosphate }\end{array}$ & FAAS & 6.10 & 30 & {$[108]$} \\
\hline Waste water & Purolite C-100 E & FAAS & 15.00 & - & {$[109]$} \\
\hline Natural water & Chromosorb-105 & FAAS & - & - & {$[110]$} \\
\hline $\begin{array}{l}\text { Tap water, river water and bottled } \\
\text { natural mineral water }\end{array}$ & Chromosorb-105 & GFAAS & 0.04 & 100 & {$[111]$} \\
\hline $\begin{array}{l}\text { Water, waste water, black tea, black } \\
\text { and hot pepper }\end{array}$ & Octadecyl-bonded silica & FAAS & 0.70 & - & {$[112]$} \\
\hline Lake water & $\begin{array}{l}\text { Amberlite XAD-2 resin functionalized with } \\
\text { 5-palmitoyl-8-hydroxyquinoline }\end{array}$ & FAAS & - & 50 & {$[113]$} \\
\hline Cadmium compounds & Chromotrope $2 \mathrm{R}$ & FAAS & - & - & [114] \\
\hline Seawater & Poly(aminophosphonic acid) & FAAS & 0.03 & - & {$[115]$} \\
\hline Seawater & Amberlite XAD-2000 & FAAS & - & - & {$[116]$} \\
\hline Water & $\begin{array}{l}\text { Activated carbon } \\
\text { Polyurethane foam }\end{array}$ & FAAS & $\begin{array}{l}3.0 \\
0.8\end{array}$ & $\begin{array}{r}63 \\
294\end{array}$ & {$[117]$} \\
\hline Water & Octadecyl-bonded silica & FAAS & 0.017 & - & {$[118]$} \\
\hline Alloy & Poly(aminophosphonic) acid & FAAS & 6.3 & 14 & {$[119]$} \\
\hline Drinking water & Poly(8-HQ-SO3H) & FAAS & 1.0 & 115 & {$[120]$} \\
\hline Seawater & Microcrystalline naphthalene & FAAS & & & {$[121]$} \\
\hline Aqueous media-synthetic sample & $\begin{array}{l}\text { Diphenylthiocarbazone-anchored on polymeric } \\
\text { microbeads }\end{array}$ & CG-AAS ${ }^{d}$ & 0.28 & 180 & {$[122]$} \\
\hline
\end{tabular}

\footnotetext{
a Flame atomic absorption spectrometry.

b Inductively coupled plasma optical emission spectrometry.

c Graphite furnace atomic absorption spectrometry.

d Gas chromatography-atomic absorption spectrometry.
} 
Table 4

On-line procedures for lead preconcentration by solid phase extraction.

\begin{tabular}{|c|c|c|c|c|c|}
\hline Sample & Sorbent & Technique & $\begin{array}{l}\text { Detection limit } \\
\left(\mu g \mathrm{~L}^{-1}\right)\end{array}$ & $\begin{array}{l}\text { Enrichment } \\
\text { factor }\end{array}$ & Reference \\
\hline Water & Activated carbon & GFAAS & $7.50 \times 10^{-3}$ & 21 & [69] \\
\hline \multirow{2}{*}{$\begin{array}{l}\text { Water, fruit juice and } \\
\text { pharmaceutical }\end{array}$} & Vermicompost & FAAS & 8.80 & 62 & {$[70]$} \\
\hline & Humic acid & & 12.10 & 83 & \\
\hline \multirow[t]{2}{*}{ Wine } & C-18 bonded silica gel & FAAS & 11.00 & 36 & [76] \\
\hline & Polyethylene & & 19.00 & 22 & \\
\hline Food & $\begin{array}{l}\text { 2-(2-Thiazolylazo)-5-dimethylaminophenol loaded } \\
\text { polyurethane foam }\end{array}$ & FAAS & 2.20 & 45 & {$[78]$} \\
\hline Seafood & $\begin{array}{l}\text { Polyurethane foam loaded with } \\
\text { 2-(2-benzothiazolylazo)-2- } p \text {-cresol (BTAC) }\end{array}$ & FAAS & 1.00 & 26 & {$[79]$} \\
\hline Wine & $\begin{array}{l}\text { 2-(2-Benzothiazolylazo)-p-cresol (BTAC) loaded } \\
\text { polyurethane foam }\end{array}$ & FAAS & 1.00 & 26 & {$[80]$} \\
\hline Natural water & $\begin{array}{l}\text { Cellulose sorbent with phosphonic acid groups } \\
\text { (Cellex P) }\end{array}$ & FAAS & 1.8 & 197 & {$[84]$} \\
\hline $\begin{array}{l}\text { Biological and saline } \\
\text { samples }\end{array}$ & $\begin{array}{l}\text { 2-(2'-Thiazolylazo })-p \text {-cresol loaded polyurethane } \\
\text { foam }\end{array}$ & ETAAS & 0.25 & 16 & {$[85]$} \\
\hline Biological samples & $\begin{array}{l}\text { 2-(2-Benzothiazolylazo)-2-p-cresol (BTAC) loaded } \\
\text { Amberlite XAD-2 }\end{array}$ & FAAS & 3.70 & 27 & {$[87]$} \\
\hline Drinking water & $\begin{array}{l}\text { 2-(5-Bromo-2-pyridylazo)-5-diethyl-aminophenol } \\
\text { (5-Br-PADAP) loaded Amberlite XAD-16 }\end{array}$ & ICP OES & 0.20 & 150 & {$[91]$} \\
\hline $\begin{array}{l}\text { Tap and river water } \\
\text { samples }\end{array}$ & 1,8-Dihydroxyanthraquinone anchored on silica gel & FAAS & 0.45 & 200 & {$[94]$} \\
\hline Water & Silica gel functionalized with methylthiosalicylate & ICP OES & 15.30 & 41 & {$[96]$} \\
\hline Spirituous beverages & Synthetic zeolite & FAAS & 1.40 & 140 & {$[123]$} \\
\hline Water and red wine & Modified rice husks & FAAS & 14.10 & 46 & {$[124]$} \\
\hline $\begin{array}{l}\text { Environmental and } \\
\text { biological samples }\end{array}$ & Acrylic acid grafted polytetrafluoroethylene fiber & FAAS & 0.26 & 49 & {$[125]$} \\
\hline Urine & Muromac A-1 & ETAAS & $4.50 \times 10^{-3}$ & - & {$[126]$} \\
\hline Water & $\mathrm{Pb}-\mathrm{Spec}(\mathrm{R})$ & FAAS & 1.00 & - & {$[127]$} \\
\hline Wine & & & 3.00 & & \\
\hline Natural waters & $\begin{array}{l}\text { 8-Hydroxyquinoline immobilized on controlled pore } \\
\text { glass }\end{array}$ & IC & 8.27 & - & {$[128]$} \\
\hline $\begin{array}{l}\text { Drinking water, sea water } \\
\text { and sediment }\end{array}$ & Chromosorb-102 & FAAS & 10.00 & 300 & [129] \\
\hline $\begin{array}{l}\text { Sediment reference } \\
\text { material and natural } \\
\text { water }\end{array}$ & Diaion HP-20 & FAAS & 2.00 & 32 & {$[130]$} \\
\hline Seawater & $\begin{array}{l}\text { 7-(4-Ethyl-1-methyloctyl)-8-hydroxiquinoline } \\
\text { (Chelex 100) 8-hydroxiquinoline Toyopearl gel } \\
\text { (TSK) }\end{array}$ & FAAS & 0.25 & & {$[131]$} \\
\hline Natural water & 2-Aminothiazole modified silica gel & FAAS & - & - & {$[132]$} \\
\hline Saline effluent & Polyurethane foam/4-(2-pyridylazo)-resorcinol & FAAS & 0.4 & 51 & {$[133]$} \\
\hline Mussel & Poly(aminophosphonic acid) & FAAS & 0.56 & 26.8 & {$[134]$} \\
\hline
\end{tabular}

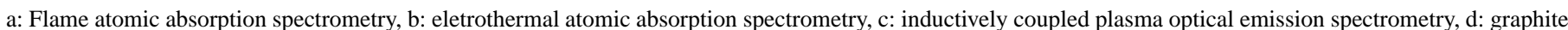
furnace atomic absorption spectrometry, e: IC: ion chromatography.

essential for a quantitative assessment of CPE efficiency [138]. Preconcentration steps based on phase separation by CPE offer a convenient alternative to conventional extraction methods. The cloud point procedure offers many advantages over conventional liquid-liquid extraction procedures, such as high extraction and preconcentration factors, operational safety due to low surfactant flammability, lower toxicity for the analyst and the environment. Moreover, inexpensive surfactants are generally used in this procedure.

The most commonly used binding site in a micelle in CPE is the hydrophobic core. Hence, the generation of a stable chelate is the main step in the majority of developed methods. However, other micelle sites are sometimes used. Under certain conditions, these areas can interact electrostatically with amphiphilic or charged substances such as metallic ions. The use of these others sites is advantageous because no chelating reagents are required in the extraction process. Thus, Luconi and coworkers extracted lead(II) ions using PONPE 7.5 as surfactant without a chelating reagent [139]. This method of extraction is possible because the surfactant forms a cationic complex with $[\mathrm{Pb}(\mathrm{OH})]^{+}$species through their polyoxyethylene groups. 
Table 5

CPE applications for lead preconcentration and determination

\begin{tabular}{|c|c|c|c|c|c|}
\hline Samples & Analytical technique & Complexing/surfactant & $\operatorname{LOD}\left(\mu \mathrm{g} \mathrm{L}^{-1}\right)$ & R.S.D. (\%) & Reference \\
\hline Saliva & FAAS & None/PONPE 7.5 & 0.3 & & [139] \\
\hline Blood & GFAAS & DDTP/Triton X-114 & 0.08 & & {$[140]$} \\
\hline River, sea and tap waters & FAAS & TAN/Triton X-114 & 1.1 & $3.5\left(20 \mu \mathrm{g} \mathrm{L}^{-1}\right)$ & [141] \\
\hline Human hairs & FAAS & DDTP/Triton X-114 & 2.86 & $1.39\left(300 \mu \mathrm{g} \mathrm{L}^{-1}\right)$ & {$[142]$} \\
\hline Tap water & ICP OES & None/PONPE 7.5 & 0.077 & & {$[143]$} \\
\hline Waters & ICP-MS & DDTP/Triton X-114 & 0.004 & $4.8\left(0.5 \mathrm{ng} \mathrm{L}^{-1}\right)$ & [144] \\
\hline Waters & GFAAS & 5-Br-PADAP/Triton X-114 & 0.08 & $2.8\left(5 \mu \mathrm{g} \mathrm{L}^{-1}\right)$ & [145] \\
\hline Biological & GFAAS & DDTP/Triton X-114 & 0.040 & & [146] \\
\hline
\end{tabular}

TAN: 1-(2-Thiazolylazo)-2-naphthol; Br-PADAP: 2-(5-bromo-2-pyridylazo)-5-(diethylamino)-phenol; DDTP: $O, O$-diethyldithiophosphate.

Table 6

Separation and preconcentration of lead using knotted reactors

\begin{tabular}{|c|c|c|c|c|c|c|}
\hline Sample & $\begin{array}{l}\text { LOD } \\
\left(\mu \mathrm{g} \mathrm{L}^{-1}\right)\end{array}$ & $\begin{array}{l}\text { Sample frequence } \\
\left(\mathrm{h}^{-1}\right)\end{array}$ & R.S.D. (\%) & $\begin{array}{l}\text { Enhancement } \\
\text { factor }\end{array}$ & Technique & Reference \\
\hline Water & 7.5 & 60 & 2.9 & 37 & FAAS & {$[150]$} \\
\hline Water, tea and medicinal herb & 8 & & 1.4 & 57 & FAAS & {$[151]$} \\
\hline $\begin{array}{l}\text { Waters and environmental reference material of soil } \\
\text { and biological reference materials of muscle and } \\
\text { human hair }\end{array}$ & 0.2 & 60 & 3.5 & 58 & FAAS & [152] \\
\hline Bovine blood and liver & 2 & 90 & 2.7 & 20 & FAAS & {$[153]$} \\
\hline Water samples and standard reference soil & $1.6^{\mathrm{a}}$ & - & 2.7 & 99 & ETAAS & {$[154]$} \\
\hline Biological and environmental samples & $4.8^{\mathrm{a}}$ & 31 & 2.1 & 125 & ETAAS & {$[155]$} \\
\hline Water & $5.0^{\mathrm{a}}$ & - & 4.9 & 142 & ETAAS & [156] \\
\hline Blood & $1.6^{\mathrm{a}}$ & - & 2.7 & 99 & ETAAS & {$[157]$} \\
\hline Urine & 0.2 & - & 2.7 & 140 & ICP OES & [158] \\
\hline Urine & 4.7 & 18 & 2.5 & 34 & ICP-MS & [159] \\
\hline Seawater & $0.028^{\mathrm{a}}$ & 21 & & 28 & ICP-MS & {$[160]$} \\
\hline
\end{tabular}

${ }^{\mathrm{a}} \mathrm{ng} \mathrm{L}^{-1}$.

Surfactant solutions provide a medium that modifies the reaction ratio, equilibrium position and spectral and analytical parameters. However, the micellar phase obtained after a CPE has physical and chemical characteristics that must be taken into account in the development of an analytical procedure. Borges et al. [140], for example, determined lead by preconcentration in a micellar phase of Triton X-114 and determination by ETAAS using Ir and Ru as permanent modifiers. This enabled them to reach a higher pyrolysis temperature and thus, eliminate the surfactant matrix before the atomization step without risk of analyte loss, as well as to avoid high background absorption.

Table 5 shows some recent CPE applications for lead determination and some analytical characteristics.

\subsection{Use of knotted reactor in preconcentration system for determination of lead}

Over the last 11 years, a number of methods have been reported using knotted reactors (KRs) as well as sorption of metallic complexes or retention of coprecipitates in on-line preconcentration systems. KRs have proved to be an attractive alternative to mini-columns $[147,148]$. The mechanisms of sorption of the complex or retention of the coprecipitate result from the action of a secondary flow with some centrifugal force in the stream, generated by changes in the flow's direction caused by the knots, which drive the complex and/or the coprecipitate towards the tubes' walls [149]. The KR has been successfully adapted for flow injection in on-line preconcentration with several spectroscopic techniques for trace metals analysis. Table 6 lists reports on the use of knotted reactors in on-line preconcentration systems for determination of lead in several types of samples.

\section{Conclusions}

Considering the poisonous nature of lead and the low concentration of this element in samples, preconcentration procedures have been devised involving separation techniques such as liquid-liquid extraction, solid phase extraction, coprecipitation and cloud point extraction. Nevertheless, each technique has its pros and cons and should therefore be chosen according to the analytical problem. Most of the proposed methods were established using solid phase extraction. In recent years, on-line systems have been preferred.

\section{Acknowledgements}

The authors gratefully acknowledge the Brazilian agencies PRONEX/Fundação de Amparo à Pesquisa do Estado da Bahia (FAPESB), Conselho Nacional de Desenvolvimento Científico e Tecnológico (CNPq) and Coordenação de Aperfeiçoamento de Pessoal de Nível Superior (CAPES) for grants and fellowships. 


\section{References}

[1] N.N. Greenwood, A. Earnshaw, Chemistry of the Elements, Pergamon Press, Oxford, 1989.

[2] B.Z. Shakhashiri, Chem. Eng. News 21 (2003) 17.

[3] http://www.theodoregray.com/periodictable/Elements/082/index.s7.html, accessed in May 14.

[4] http://www.webelements.com/webelements/elements/text/Pb/key.html, accessed in May 14.

[5] S.K. Hall, Environ. Sci. Technol. 6 (1972) 31.

[6] L.C. Mello, A. Claudino, I. Rizzatti, R.L. Bortoluzzi, D.R. Zanette, J. Braz. Chem. Soc. 16 (2005) 308.

[7] L.D. Lacerda, M.G. Ribeiro, J. Braz. Chem. Soc. 15 (2004) 931.

[8] J.F.N. Carrijo, L.C. Brasil, N.M. Melo Coelho, J. Braz. Chem. Soc. 16 (2005) 520.

[9] F.S. Felix, J. Lichtig, L.B.O. dos Santos, J.C. Masini, J. Braz. Chem. Soc. 16 (2005) 801.

[10] L.L. Embrick, K.M. Porter, A. Pendergrass, D.J. Butcher, Microchem. J. 81 (2005) 117.

[11] R.M. Harrison, D.R.H. Laxen, Lead Pollution, Chapman and Hall, London, 1981.

[12] http://www.link.med.ed.ac.uk/hew/chemical/lead.html, accessed in May 14.

[13] B. Welz, M. Sperling, Atomic Absorption Spectrometry, third ed., Wiley-VCH, 1999.

[14] B. Welz, G. Schlemmer, J.R. Mudakavi, J. Anal. At. Spectrom. 7 (1992) 1257.

[15] P.B. Barrera, R.M. Soto Ferreiro, R. Dominguez Gonzáles, Analyst 118 (1993) 665.

[16] O. Acar, Talanta 65 (2005) 672.

[17] H.B. Pereira, A.S. Luna, F.W. Herms, R.C. de Campos, J. Braz. Chem. Soc. 15 (2004) 487.

[18] C. Eloi, J.D. Robertson, V. Majidi, J. Anal. At. Spectrom. 8 (1993) 217.

[19] A. Montaser, D.W. Golightly, Inductively Coupled Plasmas in Analytical Atomic Spectrometry, second ed., VCH, New York, 1992.

[20] M.G.A. Korn, H.V. Jaeger, A.C. Ferreira, A.C.S. Costa, Spectrosc. Lett. 33 (2000) 127.

[21] Iv. Boevski, N. Daskalova, I. Havezov, Spectrochim. Acta 55B (2000) 1643.

[22] A. Mizuike, Enrichment Techniques for Inorganic Trace Analysis, Spring-Verlag, Berlin, 1983.

[23] V. Umashankar, R. Radhamani, K. Ramadoss, D.S.R. Murty, Talanta 57 (2002) 1029.

[24] K.M. Matthews, Anal. Lett. 16 (1983) 633.

[25] G.A. Peck, J.D. Smith, Anal. Chim. Acta 422 (2000) 113.

[26] P.H. Towler, J.D. Smith, D.R. Dixon, Anal. Chim. Acta 328 (1996) 53.

[27] H. Yoshikawa, T. Akiyoshi, K. Tsukada, Bunseki Kagaku 40 (1991) 175.

[28] M.S. Bispo, M.G.A. Korn, A.C.S. Costa, E.S.B. Morte, L.S.G. Teixeira, M. Korn, Spectrochim. Acta 60B (2005) 653.

[29] G. Doner, A. Ege, Anal. Chim. Acta 547 (2005) 14.

[30] U. Divrikli, L. Elci, Anal. Chim. Acta 452 (2002) 231.

[31] M. Soylak, S. Saracoglu, U. Divrikli, L. Elci, Talanta 66 (2005) 1098.

[32] T. Akagi, K. Fuwa, H. Haraguchi, Anal. Chim. Acta 177 (1985) 139.

[33] T. Akagi, H. Haraguchi, Anal. Chem. 62 (1990) 81.

[34] C.P. Weisel, R.A. Duce, J.L. Fasching, Anal. Chem. 56 (1984) 1050.

[35] X. Ma, T. Kuang, Q. Liu, Rare Met. 23 (2004) 193.

[36] L. Elci, S. Saraçoglu, Talanta 46 (1998) 1305.

[37] J.F. Wu, E.A. Boyle, Anal. Chem. 69 (1997) 2464.

[38] S. Saracoglu, M. Soylak, L. Elci, Talanta 59 (2003) 287.

[39] T. Nakamura, H. Oka, M. Ishii, J. Sato, Analyst 119 (1994) 1397.

[40] R.W. Dabeka, Sci. Total Environ. 89 (1989) 271.

[41] Y. Wu, D. Liu, Y. Zhang, Y. Peng, P. Kuang, Guangpu Shiyanshi 21 (2004) 1005.

[42] H. Sato, J. Ueda, Anal. Sci. 17 (2001) 461.
[43] P. Burba, P.G. Willmer, Fresenius Z. Anal. Chem. 329 (1987) 539.

[44] H. Chen, J. Jin, Y. Wang, Anal. Chim. Acta 353 (1997) 181.

[45] Y. Su, J. Li, H. Ma, Fenxi Shiyanshi 24 (2005) 70.

[46] S. Kagaya, M. Saiki, Z.A. Malek, Y. Araki, K. Hasegawa, Fresenius' J. Anal. Chem. 371 (2001) 391.

[47] Z. Zhuang, C. Yang, X. Wang, Fresenius' J. Anal. Chem. 355 (1996) 277.

[48] D.M. Hopkins, J. Geochem. Explor. 41 (1991) 349.

[49] D. Atanassova, V. Stefanova, E. Russeva, Talanta 47 (1998) 1237.

[50] J.C. Burridge, I.J. Hewitt, Analyst 110 (1985) 795.

[51] G.H. Morrison, H. Freiser, Solvent Extraction in Analytical Chemistry, John Wiley \& Sons, New York, 1957.

[52] B.L. Karger, An Introduction to Separation Science, John Wiley \& Sons, New York, 1973.

[53] J.M. Miller, Separation Methods in Chemical Analysis, John Wiley \& Sons Inc., New York, 1975.

[54] M.S. Cresser, Solvente Extraction in Flame Spectroscopic Analysis, Butterworths, London, 1978.

[55] Z.L. Fang, Flow Injection Separation and Preconcentration, VCH/Weinheim, 1993.

[56] V. Kuban, Crit. Rev. Anal. Chem. 22 (1991) 477.

[57] F.A.C. Amorim, S.L.C. Ferreira, Talanta 65 (2005) 960.

[58] M. Alkan, D. Kara, Instrum. Sci. Technol. 32 (2004) 291.

[59] K. Ndung'u, R.P. Franks, K.W. Bruland, A.R. Flegal, Anal. Chim. Acta 481 (2003) 127.

[60] J.H. Wang, E.H. Hansen, J. Anal. At. Spectrom. 17 (2002) 1284.

[61] J. Koksal, V. Synek, P. Janos, Talanta 58 (2002) 325.

[62] E. Carasek, J.W. Tonjes, M. Scharf, Quim. Nova 25 (2002) 748.

[63] E. Carasek, J.W. Tonjes, M. Scharf, Talanta 56 (2002) 185.

[64] D. Zendelovska, G. Pavlovska, K. Cundeva, T. Stafilov, Talanta 54 (2001) 139.

[65] I.A. Ansari, V.K. Dewani, M.Y. Khuhawar, J. Chem. Soc. Pak. 21 (1999) 359.

[66] G.J. Batterham, N.C. Munksgaard, D.L. Parry, J. Anal. At. Spectrom. 12 (1997) 1277.

[67] R. Saran, T.S. Basu Baul, P. Srinivas, D.T. Khathing, Anal. Lett. 25 (1992) 1545.

[68] V. Camel, Spectrochim. Acta Part B 58 (2003) 1177.

[69] X.G. Su, M.J. Wang, Y.H. Zhang, J.H. Zhang, H.Q. Zhang, Q.H. Jin, Talanta 59 (2003) 989.

[70] M.D. Pereira, M.A.Z. Arruda, Microchim. Acta 146 (2004) 215.

[71] S.A. Mustafa, S. Saracoglu, L. Elci, M. Dogan, Intern. J. Environ. Anal. Chem. 82 (2002) 225.

[72] M. Tuzen, I. Narin, M. Soylak, L. Elci, Anal. Lett. 37 (2004) 473.

[73] S. Tokahoglu, S. Kartal, L. Elci, B. Kor, Chem. Soc. 23 (2002) 693.

[74] Y.S. Kim, G. In, C.W. Han, J.M. Choi, Microchem. J. 80 (2005) 151.

[75] A. Ceccarini, I. Cecchini, R. Fuoco, Microchem. J. 79 (2005) 21.

[76] A.P. Fernandes, M. Moraes, J.A.G. Neto, At. Spectroc. 24 (2003) 179.

[77] M. Castillo, G. Pina-Luis, M.E. Díaz-García, I.A. Rivero, J. Braz. Chem. Soc. 16 (2005) 412.

[78] S.L.C. Ferreira, W.N.L. dos Santos, M.A. Bezerra, V.A. Lemos, J.M. Bosque-Sendra, Anal. Bioanal. Chem. 375 (2003) 443.

[79] V.A. Lemos, S.L.C. Ferreira, Anal. Chim. Acta 441 (2001) 281.

[80] V.A. Lemos, M. De La Guardia, S.L.C. Ferreira, Talanta 58 (2002) 475.

[81] A.A. Ensafi, T. Khayamian, M.H. Karbasi, Anal. Sci. 19 (2003) 953.

[82] L. Elci, Z. Arslan, J.F. Tyson, Spectrochim. Acta Part B 55 (2000) 1109.

[83] T. Seki, H. Takigawa, Y. Hirano, Y. Ishibashi, K. Oguma, Anal. Sci. 16 (2000) 513.

[84] K. Pyrzynska, M. Cheregi, Water Res. 34 (2000) 4215.

[85] O.D. Sant'ana, L.S. Jesuíno, R.J. Cassella, M.S. Carvalho, R.E. Santelli, J. Braz. Chem. Soc. 15 (2004) 96.

[86] K. Suvardhan, K. Suresh Kumar, D. Rekha, B. Jayaraj, G.K. Naidu, P. Chiranjeevi, Talanta, in press.

[87] S.L.C. Ferreira, V.A. Lemos, R.E. Santelli, E. Ganzarolli, A.J. Curtius, Microchem. J. 68 (2001) 41. 
[88] M.D. Yebra, L. Rodriguez, L. Puig, A. Moreno-Cid, Microchim. Acta 140 (2002) 219.

[89] A.C.S. Costa, L. Lopes, M.G.A. Korn, J.G. Portela, J. Braz. Chem. Soc. 13 (2002) 674

[90] S. Dadfarnia, A.M.H. Shabani, H.D. Shirie, Bull. Korean Chem. Soc. 23 (2002) 545.

[91] R.G. Wuilloud, H.A. Acevedo, F.A. Vazquez, L.D. Martinez, Anal. Lett. 35 (2002) 1649.

[92] P.K. Tewari, A.K. Singh, Talanta 56 (2002) 735.

[93] M. Kumar, D.P.S. Rathore, A.K. Singh, Fresenius J. Anal. Chem. 370 (2001) 377.

[94] A. Goswami, A.K. Singh, Talanta 58 (2002) 669.

[95] C. Ekinci, U. Koklu, Spectrochim. Acta Part B 55 (2000) 1491.

[96] A. Zougagh, A.G. Torres, E.V. Alonso, J.M.C. Pavon, Talanta 62 (2004) 503 .

[97] S. Takemori, K. Yamada, O. Itoh, N. Nanbu, Y. Akama, Bunseki Kagaku 53 (2004) 841.

[98] M. Soylak, I. Narin, M.A. Bezerra, S.L.C. Ferreira, Talanta 65 (2005) 895.

[99] M.S. Bispo, M.G.A. Korn, E.S.B. Morte, L.S.G. Teixeira, Spectrochim. Acta Part B 57 (2002) 2175.

[100] H. Matsumiya, N. Iki, S. Miyano, M. Hiraide, Anal. Bioanal. Chem. 379 (2004) 867.

[101] M.R. Ganjali, M.R. Pourjavid, L.H. Babaei, M. Salavati-Niasari, Anal. Chim. 94 (2004).

[102] M.R. Ganjali, L.H. Babaei, L.H. Badaei, G.M. Ziarani, A. Tarlani, Anal. Sci. 20 (2004) 725.

[103] P.G. Krishna, K.S. Rao, V.M. Biju, T.P. Rao, G.R.K. Naidu, Chem. Anal. 49 (2004) 383.

[104] M. Soylak, Anal. Lett. 37 (2004) 1203.

[105] G. Venkatesh, A.K. Singh, B. Venkataramani, Microchim. Acta 144 (2004) 233.

[106] M. Tuzen, M. Soylak, Anal. Chim. Acta 504 (2004) 325.

[107] H.F. Maltez, L.F.C. Melo, S.C.D. Queiroz, I.C.S.F. Jardim, A.J. Curtius, E. Carasek, Microchim. Acta 144 (2004) 17.

[108] E. Matoso, L.T. Kubota, S. Cadore, Talanta 60 (2003) 1105.

[109] E. Demirel, M. Ozcan, S. Akman, N. Tokman, J. Trace Microprobe Tech. 21 (2003) 161.

[110] A.U. Karatepe, M. Soylak, L. Elci, Anal. Lett. 36 (2003) 797.

[111] Y. Cai, G.B. Jiang, J.F. Liu, X. Liang, At. Spectrosc. 23 (2002) 52.

[112] M.R. Ganjali, F. Basiripour, M. Salavati-Niasari, Can. J. Anal. Sci. Spectros. 47 (2002) 41.

[113] H. Filik, Anal. Lett. 35 (2002) 881.

[114] S. Saracoglu, M. Soylak, L. Elci, Can. J. Anal. Sci. Spectrosc. 46 (2001) 123

[115] M.C. Yebra, N. Carro, A. Moreno-Cid, L. Puig, Field Anal. Chem. Technol. 5 (2001) 239.

[116] I. Narin, M. Soylak, L. Elci, M. Dogan, Anal. Lett. 34 (2001) 1935.

[117] J.B.B. da Silva, S.P. Quináia, M.C.E. Rolemberg, Fresenius J. Anal. Chem. 369 (2001) 657

[118] O.R. Hashemi, M.R. Kargar, F. Raoufi, A. Moghimi, H. Aghabozorg, M.R. Ganjali, Microchem. J. 69 (2001) 1.

[119] M.C. Yebra-Biurrun, M.F. Enriquez-Dominguez, A. Garcia-Garrido, A. Moreno-Cid, At. Spectrosc. 21 (2000) 225.

[120] X.Y. Zhang, Chin. J. Anal. Chem. 28 (2000) 1493.

[121] M.G.A. Korn, M.S. Bispo, M. Korn, A.B. Costa, J.C.P. Mattos, J.N.G. Paniz, E.M.M. Flores, J. Braz. Chem. Soc. 16 (2005) 1241.

[122] B. Salih, Spectrochim. Acta Part B 55 (2000) 1117.

[123] Y.P. Pena, B. Paredes, W. Rondon, M. Burguera, J.L. Burguera, C. Rondon, P. Carrero, T. Capote, Talanta 64 (2004) 1351.
[124] C.R.T. Tarley, S.L.C. Ferreira, M.A.Z. Arruda, Microchem. J. 77 (2004) 163.

[125] Z.H. Wang, Z.P. Zhang, Z.P. Wang, L.W. Liu, X.P. Yan, Anal. Chim. Acta 514 (2004) 151.

[126] Y.H. Sung, S.D. Huang, Anal. Chim. Acta 495 (2003) 165.

[127] Y. Bakircioglu, S.R. Segade, E.R. Yourd, J.F. Tyson, Anal. Chim. Acta 485 (2004) 9.

[128] M.R. Bin Abas, I.A. Takruni, Z. Abdullah, N.M. Tahir, Talanta 58 (2002) 883

[129] S. Saracoglu, L. Elci, Anal. Chim. Acta 452 (2002) 77.

[130] M. Soylak, L. Elci, Y. Akkaya, M. Dogan, Anal. Lett. 35 (2002) 487.

[131] L.R. Bravo-Sanchez, B.S. De La Riva, J.M. Costa-Fernandez, R. Pereiro, A. Sanz-Medel, Talanta 55 (2001) 1071.

[132] I.L. de Alcântara, P.S. Roldan, M.A.L. Margionte, G.R. Castro, C.C.F Padilha, A.O. Florentino, P.M. Padilha, J. Braz. Chem. Soc. 15 (2004) 366.

[133] W.N.L. dos Santos, C.M.M. dos Santos, J.L.O. Costa, H.M. Andrade, Microchem. J. 77 (2004) 123

[134] M.C. Yebra, M.F. Enriquez, A. Garcia, A. Moreno-Cid, Fresenius J. Anal. Chem. 370 (2001) 64.

[135] C.D. Stalikas, Trends Anal. Chem. 21 (2002) 343.

[136] M.A. Bezerra, M.A.Z. Arruda, S.L.C. Ferreira, Appl. Spectrosc. Rev. 40 (2005) 269.

[137] W.L. Hinze, E.A. Pramauro, Crit. Rev. Anal. Chem. 24 (1993) 133.

[138] H. Tani, T. Kamidate, H. Watanabe, J. Chromatogr. A 780 (1997) 229.

[139] M.O. Luconi, M.F. Silva, R.A. Olsina, L.P. Fernandez, Talanta 51 (2000) 123.

[140] D.L.G. Borges, M.A.M.S. Veiga, V.A.L. Frescura, B. Welz, A.J. Curtius, J. Anal. At. Spectrom. 18 (2003) 501.

[141] J. Cheng, K.C. Teo, Anal. Chim. Acta 450 (2001) 215.

[142] J.L. Manzoori, A. Bavili-Tabrizi, Anal. Chim. Acta 470 (2002) 215.

[143] M.O. Luconi, L.L. Sombra, M.F. Silva, L.D. Martinez, R.A. Olsina, L.P. Fernandez, Chem. Anal. 48 (2003) 749.

[144] M.A.M. Silva, V.L.A. Frescura, A.J. Curtius, Spectrochim. Acta B 55 (2000) 803

[145] J. Chen, S. Xiao, X. Wu, K. Fang, W. Liu, Talanta 67 (2005) 992.

[146] T.A. Maranhão, D.L.G. Borges, M.A.M.S. Veiga, A.J. Curtius, Spectrochim. Acta B 60 (2005) 667.

[147] X.P. Yan, Y. Jiang, Trends Anal. Chem. 20 (2001) 552.

[148] S. Cerutti, R.G. Wuilloud, L.D. Martinez, Appl. Spectrosc. Rev. 40 (2005) 71.

[149] Z. Fang, Flow Injection Separation and Preconcentration, VCH, New York, 1993.

[150] Q.Y. Ye, Y. Li, Y. Jiang, X.P. Yan, At. Spectrosc. 23 (2002) 154.

[151] Y. Li, Y. Jiang, X.P. Yan, W.J. Peng, Y.Y. Wu, Anal. Chem. 74 (2002) 1075 .

[152] J.S. Liu, H.W. Chen, X.Q. Mao, X. Jin, Int. J. Environ. Anal. Chem. 76 (2000) 267.

[153] Z.L. Fang, M. Sperling, B. Welz, J. Anal. At. Spectrom. 6 (1991) 301-306.

[154] H.W. Chen, J.C. Jin, Y.F. Wang, Anal. Chim. Acta 353 (1997) 181.

[155] X.P. Yan, F. Adams, J. Anal. At. Spectrom. 12 (1997) 459.

[156] M. Sperling, X.P. Yan, B. Welz, Spectrochim. Acta Part B 51 (1996) 1891

[157] E. Ivanova, W.V. Mol, F. Adams, Spectrochim. Acta Part B 53 (1998) 1041.

[158] J.A. Salonia, R.G. Wuilloud, J.A. Gasquez, R.A. Olsina, L.D. Martinez, J. Anal. At. Spectrom. 14 (1999) 1239.

[159] J.H. Wang, E.H. Hansen, J. Anal. At. Spectrom. 17 (2002) 1278.

[160] S.H. Ke, L.S. Huang, J.S. Huang, K.C. Lin, Appl. Spectrosc. 55 (2001) 604. 